\title{
Economic Value Added and Its Benefit for Owners and Managers of the Czech Company
}

(Discussion about economic value added)

\author{
Bohuslava KNAPOVÁ*
}

\section{Introduction}

It is evident today that the necessity of the value management is typical under present conditions of the globalization and competition. All business companies work with so-called theory "shareholder value". Some facts follow from the application of this theory and we should respect them when the economics is developed so quickly. There are concrete theses about the optimal allocation of resources pointing to the development of the strategic management, about the company performance measurement, about the effort how to harmonize owners' and managers' targets and interests and to create so the ethical environment with the correct manner of management and decision making of owners and managers in each Czech company.

The criterion Economic Value Added is given among performance criteria with the intention of the added value creation, which the accounting profit can't always express comprehensibly. The construction of well-known criterion Economic Value Added shows that operating profit after tax must be greater than investment capital multiplied by capital costs which are created by interests paid to investors and incomes required by shareholders. The ascertainment of criterion Economic Value Added is often connected with the part of the profit amount or certain amount of profit per share and must bring the positive value.

\# This paper was prepared in the framework of research project Development of Accounting and Financial Theory and its Application in Practice from Interdisciplinary Point of View (registered number MSM 6138439903).

* Ing. Bohuslava Knapová, CSc. - Senior Lecturer; Department of Managerial Accounting, Faculty of Finance and Accounting, University of Economics, Prague, W. Churchill Sq. 4, 13067 Prague 3, Czech Republic; <knapova@vse.cz>. 
We can see the assessment of company performance in the Income Statement of financial accounting. Such criteria as for example Economic Value Added, Earnings Before Interest and Tax, Market Value Added, Share Value Added, Cash flow return on investment capital and others are by the starting point of the strategic management and decision making owners and top managers of the Czech company. Such information methods, for example Balanced Scorecard, long-term analyses of the customer profitability analysis and sensitivity analysis (Crawford, 2008) and value instruments of output oriented management as the target costing and life cycle costing (Knapová, 2009), are used to the promotion of strategic targets so as to facilitate to the elimination of the uncertainty in the business and also to the ensuring of long-term perspectives on the performance development.

The article objective is to present the chosen synthetic criterion Economic Value Added for owners and managers on their positions, which belongs among prepared performance criteria primarily in the field of the long-term management and secondarily to emphasize its importance and using for management of main operating activities of Czech accounting entities.

\section{Criterion Economic Value Added and its importance}

\section{Concept of criterion Economic Value Added}

The performance criterion Economic Value Added was presented in 1994 year. Then it was introduced by Stern Stewart Company (Šoljaková, 2009). It represents the criterion of the so-called residual income and managerially measured profit, which should come out the economic concept of costs (Král, 2010) in the Czech practice.

The own structure of calculus of the criterion Economic Value Added goes out the ascertainment of operating profit after tax and the manner of the assessment of the investment capital and capital costs. Concretely this criterion is ascertained as the difference between net profit of the main operating (operational, entrepreneurial, business) activity before interest but after tax (NOPAT) and weighted average capital costs (WACC) multiplied by investment capital (IC), which is the long term blocked in the accounting entity and is needed for the financing of the main 
operating activity. The absolute criterion Economic Value Added is presented like $E V A=N O P A T-(W A C C \cdot I C)$.

The synthetic criterion Economic Value Added can be also determined by the relation $E V A=(R O I C-W A C C) \cdot I C$ or $(R O A-$ $W A C C) \cdot I C$, where criterion ROIC (Return on Investment Capital $)=$ net profit / investment capital, ROA (Return on Assets) = net profit / assets, $W A C C=$ weighted average capital costs and $I C=$ investment capital.

The absolute criterion Economic Value Added can be also expressed by the relation $E V A=O P-W A C C \cdot(A-S t L)$, where $O P=$ operating profit after tax, $W A C C=$ weighted average capital costs, $A=$ average amount of assets needed for realization of main operating activities and $S t L=$ average amounts of short-term liabilities rising in the connection with the main entrepreneurial activity of the accounting entity.

There are also other ways of the ascertainment of this performance synthetic absolute criterion Economic Value Added, for instance (Kislingerová, 2001) with the help of criterion $R O E$ (Return on Equity) = net profit / owner's equity, then $E V A=\left(R O E-c_{e}\right) \cdot I C$, where costs of owner's equity constitute $c_{e}$ and $I C$ is investment capital.

Although the preparation of the criterion Economic Value Added is logic matter, it is important to give right values to this criterion. First problem is such one, how to report the right amount of net operating profit after tax. It is better to identify net operating profit after tax from items of Czech Income statement which classifies costs by function than from items of nature classification of expenses (Knapová - Krabec Roubíčková, 2009). It is important that net operating profit after tax, which is reported in the result of criterion Economic Value Added, reflects actual and right company performance; problem can be for example in the items of revenues from sale of long-term operating assets, some inventories and others.

We'll not take account of financial economy result with the expression of the criterion Economic Value Added because we are interested in net operating profit after tax without the influence of participations in other companies or the manner of investment financing.

The operating profit should be taken like the relation between revenues from sale of outputs of business activities, that is finished 
products, semi-finished products and delivered services, and function or nature breakdown of costs of sold or produced outputs; in the second case we must arrange costs or revenues about stage changes of inventories of own outputs, i. e. finished products, unfinished products and semifinished products. This difference shouldn't be changed by results of transactions from other company activities, for example transactions connected with the sale of unneeded fixed assets, material and so on. It is necessary to signalize this dangerous fact, which is typical for business under conditions of Czech companies.

\section{Characteristics of categories Weighted Average Capital Costs and Investment Capital}

The assessment of capital costs includes many aspects, for example the determination of the financial structure of resources, the way of the financing, requirements of top managers and owners on the certain minimum of the capital evaluation, the relation to the profit, demands on securing of assets and others.

All these aspects are taken account of the determination of the right discount rate which in ideal case really reflects actual capital costs and eliminates so simple view which has taken account of only alternative costs and required income of the total capital.

Capital costs are the opportunity cost of the capital of owners. In the Czech practice these owners need percentage expression of Weighted Average Capital Costs including both costs of liabilities and costs of the owner's equity.

The assessment of Weighted Average Capital Costs means to make four steps (Maříková - Mařík, 2001): to determine weights of particular capital parts, to determine costs of liabilities and costs of the owner's equity, to calculate Weighted Average Capital Costs and to accomplish other adjustments.

The Investment Capital is judged by following way. Firstly, investment capital is given as result from assets in two directions: a) as long-term assets plus net working capital, where net working capital equals to the summation of current assets, for example inventories and accounts receivable, minus short-term liabilities, b) as long-term assets plus net current assets. Secondly, investment capital is taken as result 
from owner's equity and liabilities, where shows difference between owner's equity and liabilities minus short-term liabilities (without the interest). In my opinion the manner of the assessment of the amount of investment capital under point $b$ ) is made with the smallest probability.

\section{Owner's and manager's approach to criterion Economic Value Added}

The criterion Economic Value Added presents, how it succeeded to fulfill suppositions, which leaded to the acceptance of the concrete investment decision. It serves so as one of the criteria of the investment decisions in sequence to the criterion net present value.

The Czech practice confirms that foreign investors look up only some Czech companies for the evaluation of their capital just with the help of the criterion Economic Value Added, when the absolute amount of this criterion must be greater than zero.

The amount of criterion Economic Value Added can be the basis for one-criterion or more-criteria methods of performance comparison of subsidiary companies (Mallya, 2007). However some owners of incorporated parent company often define the criterion Economic Value Added for subsidiary companies externally and call for its fulfillment (Proctor, 2009).

The criterion Economic Value Added could be used as important tool of the transformation of strategic targets of the Czech company at tactical levels of time periods and to the lower structural levels of investment and profitability responsibility centers (Šoljaková, 2009).

This criterion is also the instrument, which gives information for the capital evaluation of the main operating activities, and the criterion of the appraisal of managerial decision making, when managers have got the responsibility for economical process and results of the main business activities.

Experience of Czech companies show that the absolute synthetic criterion Economic Value Added serves mainly like the criterion for owners and top managers, but it is used relatively less from the position of managers at lower managing levels for the internal performance measurement than from the view of owners. 
Czech owners must solve questions connected with the expression of the criterion Economic Value Added of following type (Knapová Popesko, 2011): how correctly to measure capital costs, how to determine the right amount of the investment capital and return on investment capital, eventually return on assets or how to work with the time horizon in the measurement of the criterion Economic Value Added.

That's why for instance the criterion Earnings Before Interest and Tax, which measures the internal entrepreneurial ability of the company (Knapová - Krabec - Roubíčková, 2009), is used in the internal structure of performance criteria much more, but it should be found rather in function Income statement of financial accounting than in the Income statement of financial accounting prepared by nature classification of expenses.

\section{Conclusion}

Owners and managers affect the contemporary business by their management and interference with business process. The decision making on the basis of performance absolute synthetic criterion Economic Value Added belongs above all to the competence just of company owners and top managers. Potential foreign investors require the positive value of this criterion in order to invest their capital to the best company. The Czech companies must give the attention to the mentioned reality.

The concept of Economic Value Added brings many advantages namely both for the performance assessment of companies and for their valuation. The main advantage for the evaluation of companies is to see in the fact that Economic Value Added is the instrument which combines the economy result with the span of the risk which is connected with the obtaining of this result and brings nearer the accounting information to the view of the capital market and investors, where these investors are by participants of this market.

The possibility to use of this criterion of financial analysis simultaneously as the tool of the valuation of a company is the other priority of Economic Value Added. This concept enables to use accounting economy result to the company valuation side by side the traditionally used method of the company valuation based on discounted cash flows. At the same time both methods permit to achieve the same result against the method of capitalized profits used in German speaking countries. 
The using of the concept Economic Value Added is the other step in the development of the theory and practice of the management of business processes of the Czech companies.

\section{References}

[1] Crawford, I. (2008): Management Accounting: A Strategic Approach. London, Financial Times Press, 2008.

[2] Kislingerová, E. (2001): Oceňování podniku. (In English: Enterprise Valuation.) Praha, C. H. Beck, 2001.

[3] Knapová, B. (2009): A Benefit of New Costing Methods for the Strategic Management. European Financial and Accounting Journal, 2009, vol. 4, no. 2, pp. 79-89.

[4] Knapová, B. - Popesko, B. (2011): Economics Value Added and Its Benefit for Owners and Managers of Czech Companies. In: SeventyFirst International Atlantic Economic Conference. Athens, IAES, 2011, s. 20.

[5] Knapová, B. - Krabec, T. - Roubíčková, J. (2009): EBIT Level of Profit and Its Use in Financial Analysis of a Private Czech Company. Oceňování, 2009, roč. 2, č. 4, s. 47-74.

[6] Král, B. et al. (2010): Manažerské účetnictví. (In English: Managerial Accounting.) Praha, Management Press, 2010.

[7] Mallya, T. (2007): Základy strategického řízení a rozhodování. (In English: Bases of Strategic Management and Decision Making.) Praha, Grada, 2007.

[8] Maříková, P. - Mařík, M. (2001): Moderní metody hodnocení výkonnosti a oceňování podniku (In English: Modern Methods of Judgement of Performance and Enterprise Valuation.) Praha, Ekopress, 2001.

[9] Proctor, R. (2009): Management Accounting for Business Decisions. London, Financial Times Press, 2009.

[10] Šoljaková, L. (2009): Strategicky orientované manažerské účetnictví. (In English: Strategic Oriented Management Accounting.) Praha, Management Press, 2009. 


\title{
Economic Value Added and Its Benefit for Owners and Managers of the Czech Company
}

\author{
Bohuslava KNAPOVÁ
}

\begin{abstract}
The paper is oriented to the area of management and decision making of company owners and managers. The absolute synthetic performance criterion Economic Value Added represents the criterion of the residual income and managerially measured profit. Concrete questions must be solved with the ascertainment of this financial criterion as for example how correctly to measure capital costs, how to determine the right amount of the investment capital and return on investment capital, eventually return on assets, or how to work with the time horizon in the measurement of Economic Value Added, because this criterion should be presented also as the important tool of the transformation of strategic targets on tactical time periods and to lower structural levels of investment and profitability responsibility centers. Economic Value Added should serve as one of criteria of investment decision and as criterion of the appraisal of managerial decision making, because just managers are responsible for the economical process and results of the main operating activities.
\end{abstract}

Key words: Management and decision making; Performance criteria; Economic Value Added; Weighted Average Capital Costs; Owners and managers.

JEL classification: M41. 